\title{
Precipitation of calcium carbonate mineral induced by viral lysis of cyanobacteria: evidence from laboratory experiments
}

\author{
Hengchao Xu ${ }^{1,2}$, Xiaotong Peng ${ }^{2}$, Shijie Bai ${ }^{2,3}$, Kaiwen $\mathrm{Ta}^{2}$, Shouye Yang ${ }^{1}$, Shuangquan $\mathrm{Liu}^{2}$, Ho Bin Jang ${ }^{3}$, and \\ Zixiao Guo ${ }^{2}$ \\ ${ }^{1}$ School of Ocean and Earth Science, Tongji University, Shanghai, China \\ ${ }^{2}$ Deep-sea Science Division, Institute of Deep-sea Science and Engineering, Chinese Academy of Science, \\ Sanya, Hainan, China \\ ${ }^{3}$ Department of Microbiology, The Ohio State University, Columbus, OH, USA
}

Correspondence: Xiaotong Peng (xtpeng@idsse.ac.cn)

Received: 17 April 2018 - Discussion started: 2 May 2018

Revised: 14 December 2018 - Accepted: 11 February 2019 - Published: 28 February 2019

\begin{abstract}
Viruses have been acknowledged as being important components of the marine system for the past 2 decades, but their role in the functioning of the geochemical cycle has not been thoroughly elucidated to date. Virus-induced rupturing of cyanobacteria is theoretically capable of releasing intracellular bicarbonate and inducing the homogeneous nucleation of calcium carbonate; however, experiment-based support for virus-induced calcification is lacking. In this laboratory study, both water carbonate chemistry and precipitates were monitored during the viral infection and lysis of host cells. Our results show that viral lysis of cyanobacteria can influence the carbonate equilibrium system remarkably and promotes the formation and precipitation of carbonate minerals. Amorphous calcium carbonate (ACC) and aragonite were evident in the lysate, compared with the $\mathrm{Mg}(\mathrm{OH})_{2}$ (brucite in this paper) precipitate in noninfected cultures, implying that a different precipitation process had occurred. Based on the carbonate chemistry change and microstructure of the precipitation, we propose that viral lysis of cyanobacteria can construct a calcification environment where carbonate is the dominant inorganic carbon species. Numerous virus particles available in lysate may coprecipitate with the calcium carbonate. The experimental results presented in this study demonstrate both the pathway and the outcome with respect to how viruses influence the mineralization of carbonate minerals. It is suggested that viral calcification offers new perspectives on mechanisms of $\mathrm{CaCO}_{3}$ biomineralization and may play a crucial role within the Earth system.
\end{abstract}

\section{Introduction}

Cyanobacteria, which are ubiquitously abundant organisms and play important roles in most aquatic environments, are generally known to influence $\mathrm{CaCO}_{3}$ precipitation by taking up inorganic carbon via photosynthesis (Obst et al., 2009b; Planavsky et al., 2009; Yang et al., 2016; Kamennaya et al., 2012; Kranz et al., 2010; Semesi et al., 2009; Riding, 2011, 2012; Merz-Preiß, 2000). Although calcium carbonate formation mediated by cyanobacteria is of great importance in sedimentary deposits, the mechanisms involved are still controversial. In many cases, the precipitation of $\mathrm{CaCO}_{3}$ by cyanobacteria has been invariably considered a noncontrolled process, promoted by either photosynthetic uptake of inorganic carbon, which raises the $\mathrm{pH}$ adjacent to cyanobacterial cells (Riding, 2006), or induced by cell-surface properties for the nucleation of $\mathrm{CaCO}_{3}$ minerals (Obst et al., $2009 b)$. In contrast, diverse cyanobacterial taxa have recently been shown to form amorphous calcium carbonate (ACC) minerals intracellularly, which have diameters of several hundreds of nanometers (Couradeau et al., 2012; Benzerara et al., 2014). The intracellular carbonate makes the mechanisms involved in calcification more confusing (Cam et al., 2015, 2016, 2018; Li et al., 2016). Thus, new pathways, in which some biological processes alter the carbonate system, are important to evaluate.

Viruses, which are vital parasites of unicellular cyanobacteria, can modulate microbial production and, in some cases, terminate plankton blooms (McDaniel et al., 2002; Bratbak et al., 1993, 1996; Suttle, 2005, 2007). It has been established 
that $3 \%-31 \%$ of free-living bacteria are infected by viruses, which can occur in excess of $10^{5}$ infectious units $\mathrm{mL}^{-1}$ (Suttle and Chan, 1994). Hence, viral lysis of microbes is certainly thought to have direct effects on both ecosystem function, involving the release of nutrients back into the environment, and the host-involved geochemical reaction (Brussaard et al., 2008; Rohwer and Thurber, 2009; Weitz and Wilhelm, 2012; Jover et al., 2014).

The thermodynamic calculation proposed by Lisle and Robbins (2016) infers that virus-induced cyanobacteria lysate can theoretically elevate the saturation index (SI) of carbonate minerals at the cellular level, by releasing cytoplasmic-associated bicarbonate. This thermodynamic calculation also highlights that the released cytoplasmassociated bicarbonate can be as much as $\sim 23$-fold greater than in the surrounding seawater, which can shift the carbonate chemistry toward the homogenous nucleation of calcium carbonate (such as vaterite). However, theoretical calculations do not take the fact that magnesium may influence the properties and behaviors of carbonate in seawater into account (Morse et al., 2007). Displacements of the acid-base carbonic equilibrium in seawater can not only form calcium carbonate minerals, but can also lead to the precipitation of $\mathrm{Mg}(\mathrm{OH})_{2}$ (Möller, 2007). It has been proposed that the dissolution of $\mathrm{Mg}(\mathrm{OH})_{2}$ in seawater is favorable for $\mathrm{CaCO}_{3}$ precipitation (Nguyen Dang et al., 2017).

Over the past few years, researchers have investigated the theory that the capsid of viruses can directly interact with elements in solution, and, thus, potentially mediate the formation and precipitation of different minerals (Daughney et al., 2004; Kyle et al., 2008; Peng et al., 2013; Pacton et al., 2014; De Wit et al., 2015; Laidler and Stedman, 2010; Orange et al., 2011). Virus-related carbonate minerals have also been reported in recent studies of biofilms from hypersaline lakes, where hypersaline carbonate minerals can precipitate at the surface of viral particles (Pacton et al., 2014; Lisle and Robbins, 2016; Perri et al., 2017). However, the pathway of the precipitation of calcium carbonate onto the surface of viruses remains poorly understood. When combined with the release of cytoplasm-associated bicarbonate, which results in the formation of energetically favored carbonate mineral, and available viral capsids for surface-induced precipitation, the comprehension of viral influence on the precipitation of carbonate is extremely limited.

Laboratory studies of viral calcification were adopted here by culturing viruses and their host Synechococcus sp. PCC 7177. Such modeling experiments do not intend to mimic the processes occurring within the cells, which remain unknown, and generally do not provide an ultimate and direct answer as to which geobiological processes are involved in biomineralization. However, these experiments constrain, to some extent, the chemical conditions necessary to predict the geochemical processes similar to those in the aquatic environment. Carbonate parameters and the cultural status were monitored to calculate the carbonate equilibrium system and
SI. Precipitates of the culture were also characterized to identify the microstructure of the minerals. Our results provide large-scale support of the importance of carbonate formation and precipitation during virus-induced cyanobacteria mortality. The extension of the viral role in mediating carbonate systems will also provide an important mechanism for $\mathrm{CaCO}_{3}$ biomineralization in the Earth system.

\section{Methods and materials}

\subsection{Cyanobacteria and viruses}

Cyanobacteria, which have a long evolutionary history and are widespread in the marine environment, are key primary producers in the surface of the world ocean system. Synechococcus sp. PCC 7177 and the viruses that infected it were isolated from surface seawater at Sanya Bay (Supplement). Synechococcus is a unicellular cyanobacterium that is very widespread in the marine environment; thus, it is welladapted for the present experiment (Fig. S1 in the Supplement). Isolated virus particles, which are $\sim 53 \mathrm{~nm}$ in diameter (Fig. S2), are classified as podovirus, based on morphology and metagenomic analysis (Fig. S3).

\subsection{Culture conditions and calcification experiments}

Cyanobacteria and viruses were grown at $25^{\circ} \mathrm{C}$, under a photon irradiance of 6000 lux, with a $12 \mathrm{~h}$ light/dark cycle (Yang et al., 2016). Before the precipitation experiments, cyanobacteria were cultivated to harvest fresh cells for the calcification experiments. Precipitation experiments were performed in sterile $4 \mathrm{~L}$ borosilicate bottles, in $0.2 \mu \mathrm{m}$-filtered artificial medium (based on F/2 media, Table 1). To minimize gas exchange with the air, filtration was performed by means of a peristaltic pump. To avoid artifacts caused by residues from previous precipitation experiments, the bottles were treated overnight in $0.1 \mathrm{M} \mathrm{HCl}$, rinsed with water several times, and then stored overnight filled with water. Two thousand milliliters of the medium was added into each bottle. The headspaces of the bottles were continuously exchanged with ambient air via a plastic membrane. The inoculation and subsampling of each experiment was performed aseptically.

Two milliliters of fresh cells from the pre-cultures was inoculated into each $2 \mathrm{~L}$ of culture media. After the lag phase (day 5$), 5 \mathrm{~mL}$ of viral stock $\left(\sim 10^{9}\right.$ virus particles per milliliter) was inoculated into one treatment (Group A) to detect the potential viral influence on carbonate chemistry. The other treatment without the inoculation of viruses was left as a control (Group B). Both treatments were run in duplicate, and subsamples from these incubations were taken simultaneously over the course of the incubations.

During the course of the study, subsamples were taken from both treatments for analysis of the cell and virus concentration, total alkalinity (TA), dissolved inorganic carbon (DIC), calcium and magnesium concentration, and the 
Table 1. Composition of the artificial seawater (modified F/2 media, final $\mathrm{pH}$ was adjust to 8). Regents were purchased from Sinopharm and Sigma-Aldrich.

\begin{tabular}{lrlr}
\hline Chemical & Amount $\left(\mathrm{g} \mathrm{L}^{-1}\right)$ & Chemical & Amount $\left(10^{-5} \mathrm{~g} \mathrm{~L}^{-1}\right)$ \\
\hline $\mathrm{NaCl}$ & 21.19 & $\mathrm{CuSO}_{4} \cdot 5 \mathrm{H}_{2} \mathrm{O}$ & 0.98 \\
$\mathrm{Na}_{2} \mathrm{SO}_{4}$ & 3.55 & $\mathrm{ZnSO}_{4} \cdot 7 \mathrm{H}_{2} \mathrm{O}$ & 2.20 \\
$\mathrm{KCl}$ & 0.60 & $\mathrm{CoCl} \cdot 6 \mathrm{H}_{2} \mathrm{O}$ & 1.00 \\
$\mathrm{NaHCO}$ & 0.29 & $\mathrm{MnCl}_{2} \cdot 4 \mathrm{H}_{2} \mathrm{O}$ & 18.0 \\
$\mathrm{KBr}$ & 0.09 & $\mathrm{Na}_{2} \mathrm{MoO}_{4} \cdot 2 \mathrm{H}_{2} \mathrm{O}$ & 0.63 \\
$\mathrm{H}_{3} \mathrm{BO}_{3}$ & 0.02 & $\mathrm{Na}_{2} \mathrm{EDTA} \cdot 2 \mathrm{H}_{2} \mathrm{O}$ & 436 \\
$\mathrm{NaF}$ & 0.003 & $\mathrm{FeCl}_{3} \cdot 6 \mathrm{H}_{2} \mathrm{O}$ & 315 \\
$\mathrm{MgCl}_{2} \cdot 6 \mathrm{H}_{2} \mathrm{O}$ & 9.59 & Vitamin $\mathrm{B} 1$ & 0.01 \\
$\mathrm{CaCl}_{2}$ & 1.01 & Vitamin biotin & 0.00005 \\
$\mathrm{SrCl}_{2} \cdot 6 \mathrm{H}_{2} \mathrm{O}$ & 0.02 & Vitamin B12 & 0.00005 \\
$\mathrm{NaNO}_{3}$ & 0.075 & & \\
$\mathrm{NaH}_{2} \mathrm{PO}_{4} \cdot \mathrm{H}_{2} \mathrm{O}$ & 0.005 & & \\
$\mathrm{Na}_{2} \mathrm{SiO}_{3} \cdot 9 \mathrm{H}_{2} \mathrm{O}$ & 0.03 & & \\
\hline
\end{tabular}

morphology of minerals. First, salinity was determined by measuring the apparent electrical conductivity. Cells and viruses were enumerated with a $1.5 \mathrm{~mL}$ solution. Filtrates (through $0.22 \mu \mathrm{m}$ filters) were collected for TA, DIC, calcium, and magnesium analysis. TA samples $(30 \mathrm{~mL})$ were stored in borosilicate bottles at room temperature. DIC samples $(5 \mathrm{~mL})$ were stored in borosilicate flasks without headspace at $4{ }^{\circ} \mathrm{C}$. Subsamples for DIC and TA were poisoned with $\mathrm{HgCl}_{2}$ solution to inhibit growth (Cao and Dai, 2011). At the end of the stationary phase (day 16), the particulate fraction of the medium $(\sim 1 \mathrm{~L})$ was harvested via centrifugation $(13000 \mathrm{~g}, 5 \mathrm{~min})$ for electronic microscopy and $\mathrm{X}$-ray diffraction study, using the methods adopted from Peng et al. (2013).

\subsection{Measurement methods}

\subsubsection{Total alkalinity and dissolved inorganic carbon}

Total alkalinity was determined by titration of $25.00 \mathrm{~mL}$ of the medium samples with $\mathrm{HCl}$ solution from the volume of $\mathrm{HCl}$ required. The instrument and program were run automatically by the Metrohm 916 Ti-Touch. The approximately $0.1 \mathrm{~N} \mathrm{HCl}$ solution was ascertained by the titration of solutions made from dried high-purity sodium carbonate and borax. The fluctuations of our total alkalinity determinations were limited to approximately $10 \mu \mathrm{M} \mathrm{kg}^{-1}$.

DIC was measured by acidification of $0.5-1.0 \mathrm{~mL}$ of water samples at the Stable Isotope Laboratory, Third Institute of Oceanography, State Oceanic Administration, China. Measurements were performed using continuous flow isotope ratio mass spectrometry (Delta V Advantage, Thermo Fisher Scientific Inc., USA), coupled with a GasBench II device.

\subsubsection{Calcium and magnesium cations}

The concentrations of magnesium and calcium cations were determined by ion chromatography (IC; Dionex ICS-900), after acidification by $1 \mathrm{NHCl}$. The precision of the IC method used was $2 \mathrm{ppm}$ for $\mathrm{Ca}^{2+}$ and $5 \mathrm{ppm}$ for $\mathrm{Mg}^{2+}$.

\subsubsection{Enumeration of cells and viruses}

For determination of cell numbers, $0.5 \mathrm{~mL}$ samples were filtered on black Nuclepore filters $(25 \mathrm{~mm}, 0.2 \mu \mathrm{m}$ pore size, Whatman) under low vacuum ( $200 \mathrm{mbar})$. Cyanobacteria were counted within $72 \mathrm{~h}$ under a Leica fluorescence microscope (Leica DM6B) with autofluorescence. The growth curves of the cultures were drawn through constant survival cell counts.

Enumeration of viruses from the culture was following Patel et al. (2007). Subsamples were first filtered $(25 \mathrm{~mm}$, $0.2 \mu \mathrm{m}$ pore size, Whatman, Inc.) to remove bacteria and large mineral particles. Aliquots of filtered supernatant were filtered through $0.02 \mu \mathrm{m}$ pore-size Anodisc 25 membrane filter (Whatman, Inc.). The Anodisc filters were then stained with a final concentration of 25X SYBR Green for $15 \mathrm{~min}$, mounted on glass microscope slides, and treated with an antifade solution. The slides were examined using an epifluorescence microscope (Leica DM6B) within $72 \mathrm{~h}$. A minimum of 10 fields of view was examined per slide.

\subsubsection{Electron microscopy}

Subsamples for the transmission electron microscope (TEM) study were fixed by the addition of glutaraldehyde (to $4 \%$ final concentration); they were then rinsed in distilled water to remove salts, mounted on copper grids, and air-dried. The TEM analysis was conducted on a JEM-2100F field emission electron microscope operated at an accelerating voltage of $200 \mathrm{kV}$. Elemental analysis was conducted at $200 \mathrm{kV}$ us- 
ing an Oxford INCA Energy TEM X-ray energy dispersive spectrometer. Elemental maps were acquired in a scanning transmission electron microscopy dark filed mode operating at $200 \mathrm{kV}$, with a focused electron beam $(1 \mathrm{~nm})$. The mineralogy of the structures in the areas of interest were determined using selected area electron diffraction (SAED).

For scanning electron microscope (SEM) analysis, dried precipitates were fixed onto aluminum stubs with two-way adherent abs and allowed to dry overnight. The samples were carbon-coated and examined with an Apreo scanning electron microscope (Thermo Fisher Scientific).

\subsubsection{X-ray Diffraction}

X-ray diffraction (XRD) was employed to characterize the bulk mineralogy of the precipitates. The subsamples were thoroughly ground, followed by analyses using a LabX XRD-6100 X-ray diffractometer with $\mathrm{Cu} \mathrm{K} \alpha$ radiation $(\lambda=$ $1.54056 \mathrm{~nm}$ ) and a $2 \theta$ angle in the range of 10 to $80^{\circ}$ at a speed of $1^{\circ} \mathrm{min}^{-1}$.

\subsection{Saturation indices calculation}

To determine the activity of the carbonate species and the degree of saturation in the solutions sampled, the geochemical computer program PHREEQC (version 3.3; Wateq4f database; United States Geological Survey - USGS, Reston, VA, USA) was used (Obst et al., 2009b). Speciation of the carbonate system and saturation state of the medium relative to a set of minerals were modeled for each of the subsample solutions. The $\mathrm{SI}$ is defined as $\mathrm{SI}=\log \left[\mathrm{IAP} / K_{\mathrm{sp}}\right.$ Mineral $]$, where IAP is the ion activity product $\left(\right.$ For $\mathrm{CaCO}_{3}, \mathrm{IAP}=$ $\left.\left[\mathrm{Ca}^{2+}\right]\left[\mathrm{CO}_{3}^{2-}\right]\right)$ and $K_{\text {sp }}$ represents the solubility product for a given temperature. The $\mathrm{pH}$ values of the subsamples were calculated using the desired total alkalinity, which was measured in Sect. 2.3.1.

\section{Results}

\subsection{Growth of cyanobacteria culture}

The color of the culture medium varied daily between the two treatments after virus-induced lysis. The supernatant of Group A, which was inoculated to allow the adsorption and infection of cyanobacteria, became clearer on the day 14 and seemed completely clear on day 17 (Fig. 1b, d). Group B, in contrast, showed some turbidity and a higher cell density at the corresponding times (Fig. 1a, c). By the time cells were lysed, the white precipitation phase had emerged in Group A (Fig. 1b, d). Cell growth was monitored over the course of 20 days by counting the autofluorescence of cyanobacteria. After the inoculation, cells exhibited a lag phase and started to grow exponentially from day 9 to day 13 , before reaching maximum cell numbers (Fig. 2a). The cell abundance of Group A was slightly lower than Group B from day 5 to day 8
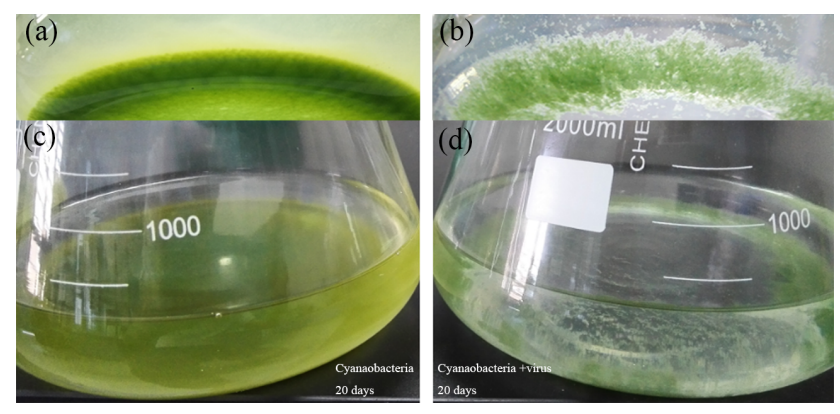

Figure 1. Photos of the culture medium at the end of the experiments. Without inoculation of the virus $(\mathbf{a}, \mathbf{c})$. White precipitates are evident in viral lysis of cyanobacteria $(\mathbf{b}, \mathbf{d})$.

(Fig. 2a). Although the cell abundance increased over the first few days, the growth rates of Group A were slightly lower and the cell number was reduced to $1.7 \times 10^{7}$ cell $\mathrm{mL}^{-1}$, compared with $1.3 \times 10^{8}$ cell $\mathrm{mL}^{-1}$ in Group B (day 19, Fig. 2a). The maximum number of virus particles occurred on day 9 (Fig. 2a). Unlike the traditional viral one-step growth curve, virus particles in the present calcification experiment decreased with the ongoing process of calcification. The burst size of a virus can be estimated by calculating the ratio of viral particles to the number of killed host cells over shorttime intervals. The lysed cells were either estimated by the decrease in the bacteria number in Group A or the increase in the bacteria number in Group B (days 8 to 9). The two estimations came up with similar results, showing that the burst size is $3.01-3.29$.

\subsection{Change of carbonate parameters}

The carbonate chemistry of the two treatments showed similar patterns during the first 10 days, but started to deviate strongly in terms of the total alkalinity (TA) and dissolved inorganic carbon (DIC) after this period, when the cell lysis rates were greater than the cell replication rates in Group A (Fig. 2b, c). In Group B, there was a negative correlation between DIC and cell growth which was a reflection of photosynthetic carbon uptake (Fig. 2a, c). When cultures were at the end of the exponential growth phase (Group B, day 14), the DIC declined to the lowest values. In Group A, in contrast, the lowest DIC values were found on day 12, when the lytic rate began to dominate cell replication. The DIC then rose to the initial level, due to re-equilibration with the atmosphere in the present open system. The TA of the two treatments also dropped during the exponential phase, reflecting a removal of cations from the solution (Fig. 2b). Compared to Group A, the TA in Group B dropped to a lower level. During the lytic phase in Group A, the TA increased again to values of $2936 \mu \mathrm{mol} \mathrm{kg}^{-1}$ in 3 days and maintained balance during the lytic cycle. Both calcium and magnesium cations were removed from the solution at the early-exponential growth phases (Fig. 3). It is interesting to note that precipitated cal- 

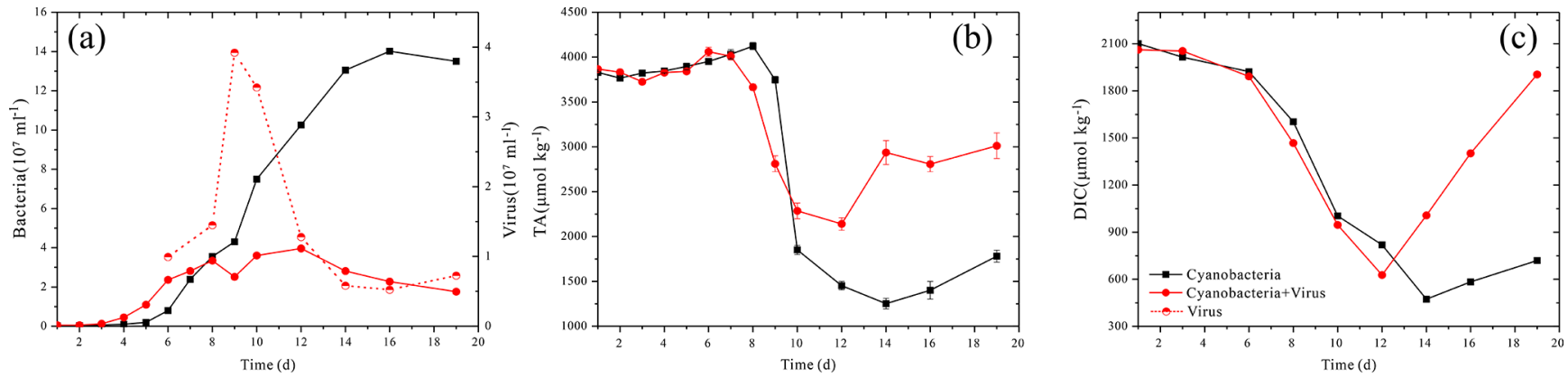

Figure 2. Changes in the solution's bacteria and virus concentration (a), total alkalinity (TA) (b) and dissolved inorganic carbon (DIC) (c).
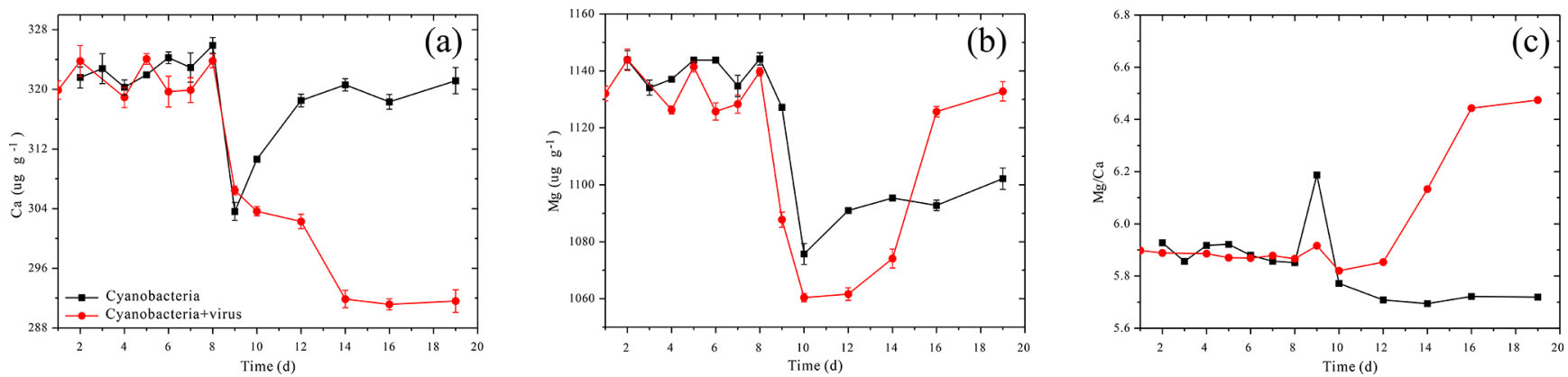

Figure 3. Changes in the solution's calcium concentration (a), magnesium concentration (b), and $\mathrm{Ma} / \mathrm{Ca}$ atomic ratio (c).

cium redissolved into the solution in Group B. In striking contrast, there was a persistent calcium removal within the viral lysate, indicating that robust virus-induced calcification had occurred (Fig. 3a, b).

\subsection{Microstructure of virus-induced carbonate precipitation}

The SEM and TEM images of the white precipitates from the viral lysate showed numerous calcium nanoparticles scattered or aggregated. These particles were in a spherical morphology, with diameters ranging from dozens of nanometers to hundreds of nanometers (Figs. 4, 5). STEM mapping and XEDS analysis showed evidence of calcium accumulation all over the particle surface (Fig. 5), as well as selected area electron diffraction (SAED) patterns with diffuse halos (Fig. 5b), confirming that the particles were ACC (Rodriguez-Blanco et al., 2008). Although $\mathrm{Mg}$ was not dominant in the particles, there were signs of $\mathrm{Mg}$ enrichment around the particles (Fig. 5c). SEM images of the nanoparticles show that they are attached to the surface of the infected cells and usually have an encrusted structure (Fig. 4d). The bulk mineralogy of the cultural deposits, based on XRD analyses, were dominated by $\operatorname{Mg}(\mathrm{OH})_{2}$ (brucite) in the uninoculated treatment, compared with aragonite in the lysate (Fig. 6).

\section{Discussion}

\subsection{Carbonate chemistry influenced by the growth of cyanobacteria}

Various studies in recent years have demonstrated the direct effects of carbonate chemistry shifts over the course of cyanobacteria growth (Dittrich et al., 2003; Kranz et al., 2010; Millo et al., 2012; Obst et al., 2009b; Yang et al., 2016). In cases where photosynthesis occurs, it results in the stimulation of cell division and DIC uptake, but no total alkalinity changes because no other sources of base are added during photosynthetic carbon uptake:

$\mathrm{HCO}_{3}^{-}+\mathrm{H}_{2} \mathrm{O} \rightarrow \mathrm{CH}_{2} \mathrm{O}+\mathrm{OH}^{-}+\mathrm{O}_{2}$.

Studies of cyanobacteria calcification always attribute the increase in $\mathrm{pH}$ to the growth of cyanobacteria, which construct a favorable calcification environment, where carbonate is the dominant inorganic carbon species and induces calcification due to the incorporation of carbonate ions into a growing $\mathrm{CaCO}_{3}$ crystal (Lee et al., 2004; Obst et al., 2009a; Kranz et al., 2010). It has been interpreted by the majority of studies that cyanobacteria calcification is restricted to certain species (Merz-Preiß, 2000; Lee et al., 2004). The calcification induced by photosynthetic acid-base equilibrium by Synechococcus sp. PCC 7177 in the present study seems to be transitional and unable to calcify to the extent that stable $\mathrm{CaCO}_{3}$ precipitates are formed. This is inferred based 

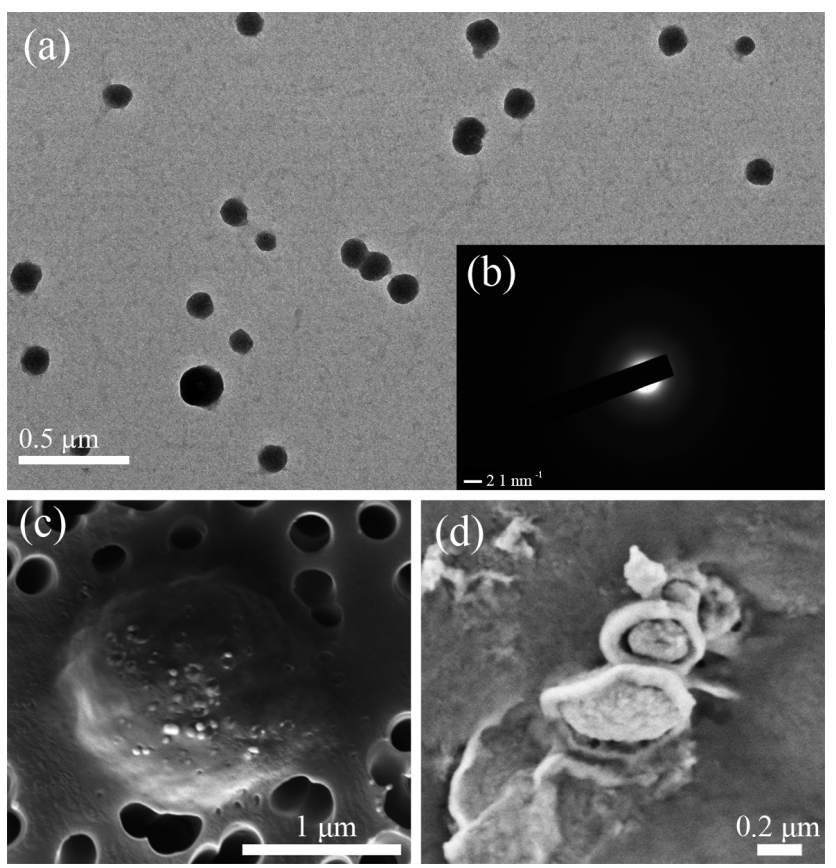

Figure 4. Electron microscope images show the formation of ACC nanoparticles in the viral lysate. (a) Nanoparticles with a diameter of approximately 50-200 $\mathrm{nm}$ are scattered in the viral lysate. (b) A selected area of the electron diffraction pattern of ACC, revealing only diffuse rings, which are related to poorly ordered materials. (c) Back scattered-electron imaging photomicrographs of host cells infected by virus and mineral particles. (d) Nanoparticles with an encrusted structure.

on the observation that cations are re-released into the solution in Group B. Fixed $\mathrm{Ca}^{2+}$ redissolves to the concentration equivalent of the former concentration (Fig. 3a). On day 8 , however, there was an evident decrease in the calcium concentration, accompanied by a decrease of TA, which implies that calcium carbonate was formed and separated from the filtrate (Fig. 3a). Photosynthetic carbon uptake (Eq. 1) raised the $\mathrm{pH}$ values of the medium, leading to the formation of $\mathrm{CaCO}_{3}$. This $\mathrm{CaCO}_{3}$ phase can be recognized as ACC, based on electron microscope images (Figs. 4, 5) and the fact that it is unstable. ACC, which has received relatively little attention as one of the metastable $\mathrm{CaCO}_{3}$ phases, has been increasingly recognized as a precursor for the formation of crystalline calcium carbonate (Cartwright et al., 2012; Weiner and Addadi, 2011). ACC may precipitate virtually instantaneously when conditions promote high local supersaturation for short periods of time (Blue et al., 2017; Cartwright et al., 2012). Although the SI of the ACC was $<0$ (Table 2), which implies non-spontaneous ACC formation within the solution, the growth of cyanobacteria in the present experiment created an ACC-favorable microenvironment on days $8-10$, reflected by the removal of $\mathrm{Ca}^{2+}$.

Magnesium, which is actually precipitated as $\mathrm{Mg}(\mathrm{OH})_{2}$ from the solution, is also responsible for removing TA from
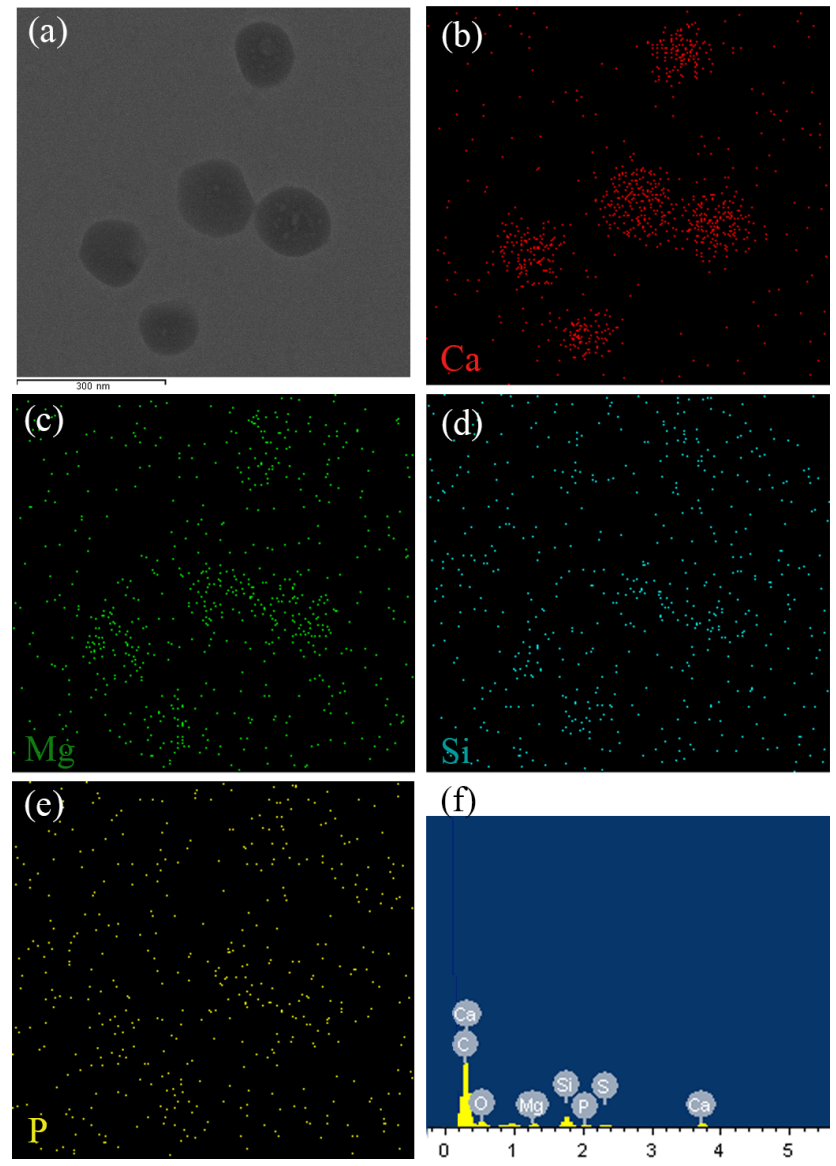

Figure 5. Chemical composition of ACC nanoparticles. (a) STEM images showing ACC nanoparticles. (b, $\mathbf{c}, \mathbf{d}, \mathbf{e})$ XEDS maps of $\mathrm{Ca}$, $\mathrm{Mg}, \mathrm{Si}$, and $\mathrm{P}$, respectively, showing that $\mathrm{ACC}$ is composed mainly of Ca. An EDS spectrum of the nanoparticle shows a small peak of element P (f). However, the P signal from the STEM mapping is not consistent with the nanoparticles (e).

the cyanobacteria culture. It has been demonstrated that supersaturated $\mathrm{Mg}(\mathrm{OH})_{2}$ can precipitate at local alkaline conditions with $\mathrm{pH}>9.30$ (Möller, 2007). The SIs, which were determined using the PHREEQC software, yielded values of $>0$ for $\mathrm{Mg}(\mathrm{OH})_{2}$ during the first 8 days $(0.34$ to 1.15$)$ and values of $<0$ after day $10(-1.47$ to -0.15$)$ in Group B (Table 2). As DIC transportation by cyanobacteria proceeded, the $\mathrm{pH}$ of the growth medium increased (Tables 2, S1 in the Supplement), leading to the formation of $\operatorname{Mg}(\mathrm{OH})_{2}$ in the supersaturated state (Eqs. 1, 2). The emergence of $\mathrm{Mg}(\mathrm{OH})_{2}$ crystal formation has also been reported in coral microbial biofilms (Nothdurft et al., 2005) and cultures of diatoms (Tesson et al., 2008), where high-pH and low- $p \mathrm{CO}_{2}$ microenvironments are created by biological activities such as that of the cyanobacteria in the present study.

$\mathrm{Mg}^{2+}+2 \mathrm{OH}^{-} \rightarrow \mathrm{Mg}(\mathrm{OH})_{2}$.

Upon the mass consumption of DIC by photosynthesis and the fixation of calcium, cell growth seems to slow down 


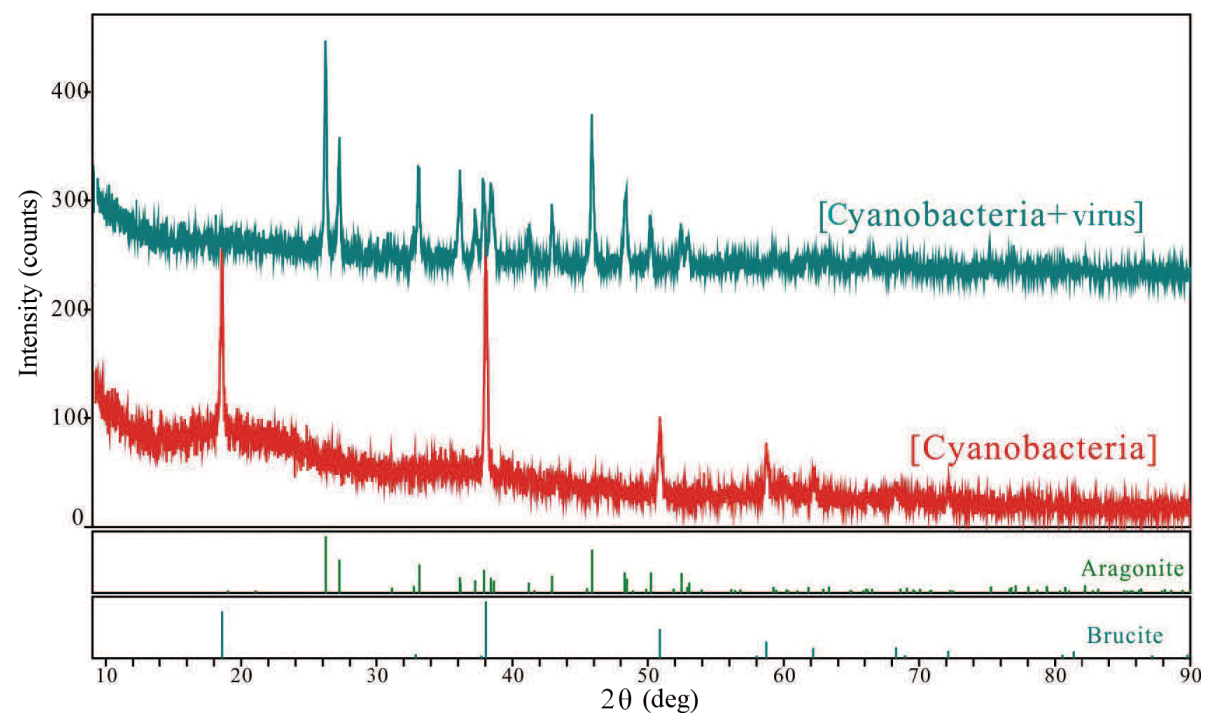

Figure 6. Typical X-ray diffraction patterns collected for each polymorph that formed in this study.

Table 2. Saturation indices calculated from culture system by PHREEQC.

\begin{tabular}{llrrrrrr}
\hline & Saturation & & \multicolumn{5}{c}{ Time (day) } \\
& index & 6 & 8 & 10 & 12 & 14 & 16 \\
\hline Cyanobacteria & $\mathrm{pH}$ & 9.56 & 9.96 & 8.66 & 8.95 & 9.32 & 9.29 \\
& Aragonite & 1.34 & 1.35 & 0.56 & 0.69 & 0.65 & 0.73 \\
& $\mathrm{Mg}(\mathrm{OH})_{2}$ & 0.34 & 1.15 & -1.47 & -0.89 & -0.15 & -0.2 \\
& $\mathrm{ACC}$ & -0.72 & -0.71 & -1.50 & -1.37 & -1.41 & -1.33 \\
& Vaterite & 0.92 & 0.93 & 0.14 & 0.27 & 0.23 & 0.31 \\
\hline Cyanobacteria + virus & $\mathrm{pH}$ & 9.65 & 9.85 & 8.87 & 9.89 & 9.93 & 9.74 \\
& Aragonite & 1.36 & 1.3 & 0.68 & 0.92 & 1.12 & 1.1 \\
& $\mathrm{Mg}(\mathrm{OH})_{2}$ & 0.52 & 0.92 & -1.06 & 0.93 & 1.06 & -0.02 \\
& $\mathrm{ACC}$ & -0.70 & -0.76 & -1.38 & -1.14 & -0.94 & -0.96 \\
& Vaterite & 0.94 & 0.88 & 0.26 & 0.50 & 0.70 & 0.68 \\
\hline
\end{tabular}

(days 8-9, Fig. 2a). In the present open system, atmospheric $\mathrm{CO}_{2}$ is dissolved in water and changes the acid-base balance of the system. Dissolved carbon is present in the form of bicarbonate at the present $\mathrm{pH}$ level:

$2 \mathrm{CO}_{2}+\mathrm{CO}_{3}^{2-}+\mathrm{OH}^{-}+\mathrm{H}_{2} \mathrm{O} \rightarrow 3 \mathrm{HCO}_{3}^{-}$.

The reaction represented by Eq. (3) in Group B is based on the continuous decrease of DIC (days 10-14). On days 910 , there was an insufficient amount of carbon for photosynthetic carbon to be concentrated in the form of $\mathrm{CO}_{2}$ or $\mathrm{HCO}_{3}^{-}$ (Miller et al., 1990). Nevertheless, cyanobacteria grew vigorously from day 10 to day 14 (Fig. 2a). The consumption of $\mathrm{CO}_{3}^{2-}$ and $\mathrm{OH}^{-}$led the unstable minerals, such as ACC and $\mathrm{Mg}(\mathrm{OH})_{2}$, to dissolve in the solution. Especially for ACC, a robust carbon concentration inhibits the transformation of ACC to a more stable carbonate phase such as aragonite. The $\mathrm{pH}$ values calculated by PHREEQC after day 10 decreased to 8.66 , at which point $\mathrm{Mg}(\mathrm{OH})_{2}$ formation could not occur spontaneously. Consequently, with the growth of cyanobacteria, carbonate alkalinity limitation leads to the redissolution of calcium and magnesium minerals.

\subsection{Carbonate chemistry influenced by viral lysis of cyanobacteria}

It seems that the two treatments of the tested culture grew at similar rates and reached similar cell densities during the first 8 days, despite inoculation with viruses (Fig. 2a). However, when lytic rates exceeded bacterial replication (day 8), $\mathrm{Mg}^{2+}$ began to recover to its initial level, but $\mathrm{Ca}^{2+}$ was simultaneously further removed, presenting distinct variations between the two treatments.

With regard to magnesium, which is immobilized from the solution in the form of $\mathrm{Mg}(\mathrm{OH})_{2}$, the resulting mineral grains are unstable. It has been suggested that $\mathrm{Mg}(\mathrm{OH})_{2}$ may not be preserved over longer time frames, possibly being dissolved in the undersaturated state (Nothdurft et al., 2005). 
There is a strong positive correlation between $\mathrm{Mg}^{2+}$ and DIC recovered after day 12 in Group A, which is the time point at which the lytic rate begins to dominate cell replication. In the present open system, atmospheric $\mathrm{CO}_{2}$ is dissolved in water and changes the acid-base balance of the system. Hence, $\mathrm{Mg}(\mathrm{OH})_{2}$ can dissolve with acidification during the culture of cyanobacteria:

$\mathrm{Mg}(\mathrm{OH})_{2}+\mathrm{CO}_{2} \rightarrow \mathrm{Mg}^{2+}+\mathrm{HCO}_{3}^{-}+\mathrm{H}_{2} \mathrm{O}$.

The release of extra bicarbonate during the dissolution of $\mathrm{Mg}(\mathrm{OH})_{2}$ also contributes to the TA recovery after day 12 .

Conversely, it should be noted that, with the aid of the virus, photosynthetic uptake of inorganic carbon decreases. Calcium, which is in the form of ACC during the growth of cyanobacteria, is formed in a stable carbonate environment, where Eq. (3) cannot take place (days 8-12). The atmospheric $\mathrm{CO}_{2}$ exchange is neutralized by $\mathrm{Mg}(\mathrm{OH})_{2}$, as discussed above (days 12-16). $\mathrm{Mg}(\mathrm{OH})_{2}$ dissolution in seawater controls the $\mathrm{pH}$ and $\mathrm{Mg} / \mathrm{Ca}$ ratios and is recognized as a key factor inhibiting calcite and vaterite growth and precipitation (Nguyen Dang et al., 2017). Thus, a microenvironment favorable for calcification is available after the viral lysis of cyanobacteria and deposition of aragonite carbonate minerals.

\subsection{Virus-induced carbonate precipitation}

The aggregates of aragonite in viral lysate were confirmed using XRD (Fig. 6). The fact that various physicochemical factors control the formation of the $\mathrm{CaCO}_{3}$ polymorph and that aragonite tends to precipitate under a high molar ratio of $\mathrm{Mg} / \mathrm{Ca}$ has been extensively investigated (Folk, 1974; Berner, 1975). Nevertheless, the microenvironment maintained by the growth of Synechococcus sp. PCC 7177 could not overcome the activation energy barriers for the formation of aragonite, according to the evidence presented by XRD and the carbonate chemistry changes in Group B. TEM images revealed no order in the majority of the particles detected (Figs. 4, 5), which was confirmed by the diffuse rings in the selected area electron diffraction patterns and the appearance of nanodomains within the ACC particles (Rodriguez-Blanco et al., 2008). Unlike Group B, with the aid of the viral cycle and the lysis of the host, the dissolution of carbonate did not seem to occur, and a more stable mineral formed in Group A.

Here, a possible model for calcium carbonate precipitation induced by viral lysis of cyanobacteria is proposed by considering the carbonate chemical changes and microstructures (Fig. 7). As bicarbonate transport by cyanobacteria and intracellular conversion to $\mathrm{CO}_{2}$ for photosynthesis proceeded, the $\mathrm{pH}$ of the ambient waters increased, leading to the formation of $\operatorname{Mg}(\mathrm{OH})_{2}$ and ACC. If no viruses were available, cell growth and replication would consume the bicarbonate. Atmospheric $\mathrm{CO}_{2}$ dissolves in water but cannot do so in the form of $\mathrm{CO}_{2}$ or $\mathrm{HCO}_{3}^{-}$for photosynthesis, due to

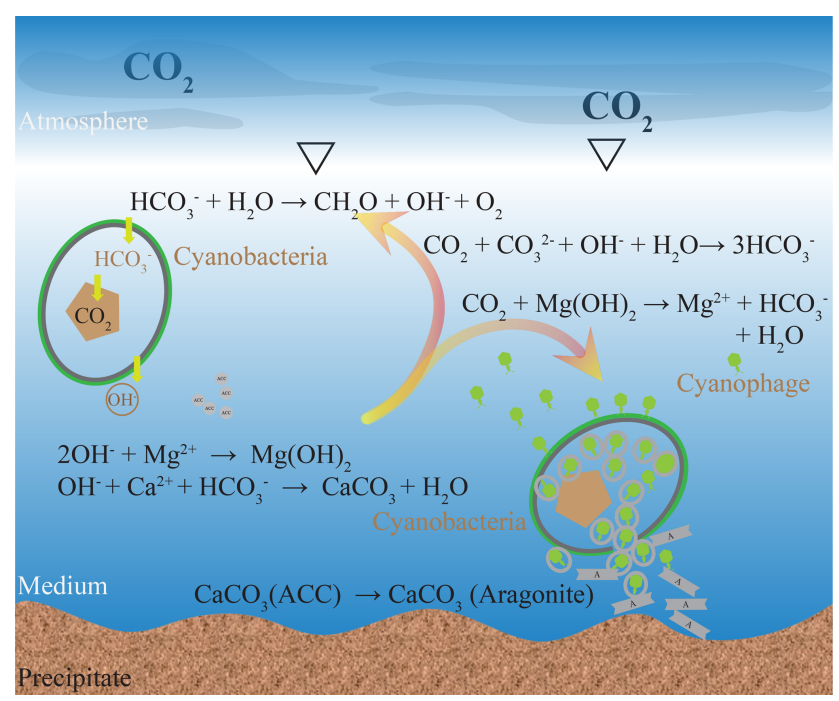

Figure 7. Formation model of the carbonate mineral induced by viral lysis of the cyanobacteria. Although the chemical environment may be favorable for mineral precipitation during photosynthesis, it is unable to facilitate mineralization to the extent that stable $\mathrm{CaCO}_{3}$ precipitates are formed. During the viral lysis of cyanobacteria, there is a small percentage of uninfected cells that require bicarbonate; therefore, $\mathrm{Mg}(\mathrm{OH})_{2}$ dissolved to neutralize the dissolution of $\mathrm{CO}_{2}$. Thus, the viral lysis of cyanobacteria construct a calcification environment where carbonate is the dominant inorganic carbon species. Numerous virus particles available in lysate may coprecipitate with the calcium carbonate.

the high $\mathrm{pH}$. Alternatively, dissolved $\mathrm{CO}_{2}$ reacts with $\mathrm{OH}^{-}$ and $\mathrm{Mg}(\mathrm{OH})_{2}$ resulting in dissolved carbon in the form of $\mathrm{HCO}_{3}^{-}$for cyanobacteria. However, when cells are infected by viruses, there is a small percentage of uninfected cells that require bicarbonate. Only $\mathrm{Mg}(\mathrm{OH})_{2}$ dissolved to neutralize the dissolution of $\mathrm{CO}_{2}$ and precipitation of calcium carbonate will continue.

Preliminary investigations have also demonstrated that viruses from hypersaline lakes are incorporated in biogenic carbonate, suggesting that viruses may be mistaken for nanobacteria and may play a role in initiating calcification (De Wit et al., 2015; Pacton et al., 2014; Perri et al., 2017). The viral drive during the biogenic carbonate precipitation in hypersaline lakes is attributed to either an indirect route, involving silicified viruses as an intermediate phase during diagenesis (Pacton et al., 2014), or a direct incorporation of amino acids polymerized with viral proteins into growing high-Mg calcite crystals (De Wit et al., 2015). The encrusted structure indicated by SEM images may support the hypothesis of carbonate formation on and near the virus particles (Fig. 4d). Coprecipitation of viruses and calcium carbonate is also supported by the number of viruses floating in solution. Subsamples for the enumeration of virus particles were filtered to remove precipitated minerals. The yield of the filtrate may preclude viruses incorporated in minerals. This is a rea- 
sonable explanation as to why virus numbers did not increase exponentially, despite the bursting of host cells (Fig. 2a). Viral infection does not result in the immediate lysis of the host cell: dormancy occurs, while viruses integrate their genome with host DNA, and the replication along with it is relatively harmless. When the reproductive cycle initiates, the virus attacks and breaks down the cell wall peptidoglycan, which is an essential structure that protects the cell protoplast from mechanical damage and from osmotic rupture (Middelboe and Jørgensen, 2006). Thus, we propose that $\mathrm{Ca}^{2+}$ has unfettered access to the intracellular space and reacts with cytoplasmic alkalinity (Fig. 7). When $\mathrm{Ca}^{2+}$ accesses the intracellular space, the existence of the capsid, synthesized by viral DNA, provides a surface for the initial calcification (Fig. 7). Calcification involves the addition of material to the preexisting viral surfaces, which may be similar to the mineralized viruses in microbial mat from hot springs (Peng et al., 2013) or hypersaline lakes (Pacton et al., 2014; De Wit et al., 2015; Perri et al., 2017).

The pathway of virus-induced calcification during the lysis of the host cells was determined by experimental study and expands the mechanisms of $\mathrm{CaCO}_{3}$ biomineralization. It may also be helpful to recognize the recent identification of accounted fractions of marine calcium carbonate particles in seawater (Heldal et al., 2012). Owing to the fact that biologically mediated $\mathrm{CaCO}_{3}$ precipitation is one of the fundamental processes in the carbon cycle (Ridgwell and Zeebe, 2005; Planavsky et al., 2009; Riding, 2011; Kamennaya et al., 2012), the study of viral impact is important regarding an understanding of the carbon cycling on both the global and regional scales. For example, so-called "whiting events", which refer to events with high levels of suspended, finegrained $\mathrm{CaCO}_{3}$ precipitation, have long been spectacular and extensively investigated $\mathrm{CaCO}_{3}$ precipitation events due to their controversial origin (Wright and Oren, 2005; Morse et al., 2003). Clear evidence of net carbonate precipitation from the waters' culturing cyanobacteria and viruses suggest that the release of the virus during plankton bloom may stimulate virus-induced $\mathrm{CaCO}_{3}$ precipitation, representing one potential whiting mechanism for $\mathrm{CO}_{2}$ sequestration. Furthermore, in view of the virus-induced carbonate deposition and the increased $\mathrm{Mg} / \mathrm{Ca}$ ratio of the medium (Fig. 3c), the possibility that viral processes alter seawater $\mathrm{Mg} / \mathrm{Ca}$ ratios, which are an important proxy for reconstructing the paleoenvironment (Lear et al., 2000), is thus important to evaluate.

\section{Conclusion}

First, we provide a detailed view of changes in carbonate chemistry and mineral composition during viral infection and lysis of cyanobacteria. ACC and aragonite were evident in the lysate, which differed substantially from the lack of calcification in the noninfected culture. We infer that viral lysis of cyanobacteria can construct an environment of calci- fication, where carbonate is the dominant inorganic carbon species. Moreover, potential mechanisms involving viruses acting as nucleation sites are also discussed. In summary, our results expand the role of viruses in mediating geochemical cycles and provide new perspectives on mechanisms of $\mathrm{CaCO}_{3}$ biomineralization.

Data availability. Data used to generate Figs. 2 and 3 are given in the Supplement. Genomic sequences are deposited at NCBI Sequence Read Archive (accession nos. MH791327 and PRJNA522368).

Supplement. The supplement related to this article is available online at: https://doi.org/10.5194/bg-16-949-2019-supplement.

Author contributions. This work was designed by HX, XP, and SY. Experimental work was performed by HX, SB, KT, SL, and ZG. SB and HBJ analyzed genomic sequences. HX and SB led the writing of the paper and prepared the figures with contributions from all co-authors.

Competing interests. The authors declare that they have no conflict of interest.

Acknowledgements. The authors would like to acknowledge Dezhang Ren at Shanghai Jiaotong University for his help with the XRD analysis. The authors are also indebted to Ling $\mathrm{Li}$ and Weijia Zhang at the Institute of Deep-sea Science and Engineering for their assistance with cyanobacteria identification. Financial support for this research came from the "National Key R\&D Program of China" (grant no. 2018YFC0309802), the "National Natural Science Foundation of China" (grant nos. 41506139 and 41506097), the "Strategic Priority Research Program" of the Chinese Academy of Science (grant no. XDB06020000), the "National Key Basic Research Program of China" (grant no. 2015CB755905), and the "Natural Science Foundation of Hainan Province, China" (grant no. 20164175). Finally, we are greatly indebted to two anonymous journal reviewers and the journal associate editor, Lennart de Nooijer, for their critical comments on an earlier version of this paper.

Edited by: Lennart de Nooijer

Reviewed by: two anonymous referees 


\section{References}

Benzerara, K., Skouripanet, F., Li, J., Ferard, C., Gugger, M., Laurent, T., Couradeau, E., Ragon, M., Cosmidis, J., and Menguy, $\mathrm{N}$.: Intracellular Ca-carbonate biomineralization is widespread in cyanobacteria, P. Natl. Acad. Sci. USA., 111, 10933-10938, https://doi.org/10.1073/pnas.1403510111, 2014.

Berner, R. A.: The role of magnesium in the crystal growth of calcite and aragonite from sea water, Geochim. Cosmochim. Ac., 39, 489-504, https://doi.org/10.1016/0016-7037(75)90102-7, 1975.

Blue, C. R., Giuffre, A., Mergelsberg, S., Han, N., De Yoreo, J. J., and Dove, P. M.: Chemical and physical controls on the transformation of amorphous calcium carbonate into crystalline $\mathrm{CaCO}_{3}$ polymorphs, Geochim. Cosmochim. Ac., 196, 179-196, https://doi.org/10.1016/j.gca.2016.09.004, 2017.

Bratbak, G., Egge, J. K., and Heldal, M.: Viral mortality of the marine alga Emiliania huxleyi (Haptophyceae) and termination of algal blooms, Mar. Ecol.-Prog. Ser., 93, 39-48, https://doi.org/10.3354/meps093039, 1993.

Bratbak, G., Wilson, W., and Heldal, M.: Viral control of Emiliania huxleyi blooms?, J. Marine. Syst., 9, 75-81, https://doi.org/10.1016/0924-7963(96)00018-8, 1996.

Brussaard, C. P., Wilhelm, S. W., Thingstad, F., Weinbauer, M. G., Bratbak, G., Heldal, M., Kimmance, S. A., Middelboe, M., Nagasaki, K., and Paul, J. H.: Global-scale processes with a nanoscale drive: the role of marine viruses, ISME J., 2, 575-578, https://doi.org/10.1038/ismej.2008.31, 2008.

Cam, N., Georgelin, T., Jaber, M., Lambert, J. F., and Benzerara, K.: In vitro synthesis of amorphous Mg-, Ca-, Sr- and Ba-carbonates: What do we learn about intracellular calcification by cyanobacteria?, Geochim. Cosmochim. Ac., 161, 36-49, https://doi.org/10.1016/j.gca.2015.04.003, 2015.

Cam, N., Benzerara, K., Georgelin, T., Jaber, M., Lambert, J.-F., Poinsot, M., Skouri-Panet, F., and Cordier, L.: Selective uptake of alkaline earth metals by Cyanobacteria forming intracellular carbonates, Environ. Sci. Technol., 50, 11654-11662, https://doi.org/10.1021/acs.est.6b02872, 2016.

Cam, N., Benzerara, K., Georgelin, T., Jaber, M., Lambert, J. F., Poinsot, M., Skouri-Panet, F., Moreira, D., López-García, P., Raimbault, E., Cordier, L., and Jézéquel, D.: Cyanobacterial formation of intracellular Ca-carbonates in undersaturated solutions, Geobiology, 16, 49-61, https://doi.org/10.1111/gbi.12261, 2018.

Cao, Z. and Dai, M.: Shallow-depth $\mathrm{CaCO}_{3}$ dissolution: Evidence from excess calcium in the South China Sea and its export to the Pacific Ocean, Global Biogeochem. Cy., 25, GB2019, https://doi.org/10.1029/2009GB003690, 2011.

Cartwright, J. H. E., Checa, A. G., Gale, J. D., Gebauer, D., and Sainz-Díaz, C. I.: Calcium carbonate polyamorphism and its role in biomineralization: How many amorphous calcium carbonates are there?, Angew. Chem. Int. Edit., 51, 11960-11970, https://doi.org/10.1002/anie.201203125, 2012.

Couradeau, E., Benzerara, K., Gérard, E., Moreira, D., Bernard, S., Brown, G. E., and López-García, P.: An early-branching microbialite cyanobacterium forms intracellular carbonates, Science, 336, 459-462, https://doi.org/10.1126/science.1216171, 2012.

Daughney, C. J., Châtellier, X., Chan, A., Kenward, P., Fortin, D., Suttle, C. A., and Fowle, D. A.: Adsorption and precipitation of iron from seawater on a ma- rine bacteriophage (PWH3A-P1), Mar. Chem., 91, 101-115, https://doi.org/10.1016/j.marchem.2004.06.003, 2004.

De Wit, R., Gautret, P., Bettarel, Y., Roques, C., Marlière, C., Ramonda, M., Nguyen Thanh, T., Tran Quang, H., and Bouvier, T.: Viruses occur incorporated in biogenic high-Mg calcite from hypersaline microbial mats, PLoS ONE, 10, e0130552, https://doi.org/10.1371/journal.pone.0130552, 2015.

Dittrich, M., Müller, B., Mavrocordatos, D., and Wehrli, B.: Induced calcite precipitation by cyanobacterium Synechococcus, Acta Hydroch. Hydrob., 31, 162-169, https://doi.org/10.1002/aheh.200300486, 2003.

Folk, R. L.: The natural history of crystalline calcium carbonate: effect of magnesium content and salinity, J. Sediment. Res., 44, 40-53, https://doi.org/10.1306/74d72973-2b21-11d7$8648000102 \mathrm{c} 1865 \mathrm{~d}, 1974$.

Heldal, M., Norland, S., Erichsen, E. S., Thingstad, T. F., and Bratbak, G.: An unaccounted fraction of marine biogenic $\mathrm{CaCO}_{3}$ particles, PLoS ONE, 7, e47887, https://doi.org/10.1371/journal.pone.0047887, 2012.

Jover, L. F., Effler, T. C., Buchan, A., Wilhelm, S. W., and Weitz, J. S.: The elemental composition of virus particles: implications for marine biogeochemical cycles, Nat. Rev. Microbiol., 12, 519528, https://doi.org/10.1038/nrmicro3289, 2014.

Kamennaya, N., Ajo-Franklin, C., Northen, T., and Jansson, C.: Cyanobacteria as Biocatalysts for Carbonate Mineralization, Minerals, 2, 338-364, https://doi.org/10.3390/min2040338, 2012.

Kranz, S. A., Gladrow, D. W., Nehrke, G., Langer, G., and Rosta, B.: Calcium carbonate precipitation induced by the growth of the marine cyanobacteria Trichodesmium, Limnol. Oceanogr., 55, 2563-2569, https://doi.org/10.4319/lo.2010.55.6.2563, 2010.

Kyle, J. E., Pedersen, K., and Ferris, F. G.: Virus mineralization at low $\mathrm{pH}$ in the Rio Tinto, Spain, Geomicrobiol. J., 25, 338-345, https://doi.org/10.1080/01490450802402703, 2008.

Laidler, J. R. and Stedman, K. M.: Virus silicification under simulated hot spring conditions, Astrobiology, 10, 569-576, https://doi.org/10.1089/ast.2010.0463, 2010.

Lear, C. H., Elderfield, H., and Wilson, P. A.: Cenozoic deep-sea temperatures and global ice volumes from $\mathrm{Mg} / \mathrm{Ca}$ in benthic foraminiferal calcite, Science, 287, 269-272, https://doi.org/10.1126/science.287.5451.269, 2000.

Lee, B. D., Apel, W. A., and Walton, M. R.: Screening of cyanobacterial species for calcification, Biotechnol. Progr., 20, 13451351, https://doi.org/10.1021/bp0343561, 2004.

Li, J., Margaret Oliver, I., Cam, N., Boudier, T., Blondeau, M., Leroy, E., Cosmidis, J., Skouri-Panet, F., Guigner, J.-M., Férard, C., Poinsot, M., Moreira, D., Lopez-Garcia, P., Cassier-Chauvat, C., Chauvat, F., and Benzerara, K.: Biomineralization patterns of intracellular carbonatogenesis in Cyanobacteria: Molecular Hypotheses, Minerals, 6, 10, https://doi.org/10.3390/min6010010, 2016.

Lisle, J. T. and Robbins, L. L.: Viral lysis of photosynthesizing microbes as a mechanism for calcium carbonate nucleation in seawater, Front. Microbiol., 7, 1958, https://doi.org/10.3389/fmicb.2016.01958, 2016.

McDaniel, L., Houchin, L. A., Williamson, S. J., and Paul, J. H.: Plankton blooms: Lysogeny in marine Synechococcus, Nature, 415, 496-496, 2002. 
Merz-Preiß, M.: Calcification in Cyanobacteria, in: Microbial Sediments, edited by: Riding, R. E. and Awramik, S. M., Springer Berlin Heidelberg, Berlin, Heidelberg, 50-56, 2000.

Middelboe, M. and Jørgensen, N.: Viral lysis of bacteria: an important source of dissolved amino acids and cell wall compounds, J. Mar. Biol. Assoc. UK, 86, 605-612, 2006.

Miller, A. G., Espie, G. S., and Canvin, D. T.: Physiological aspects of $\mathrm{CO}_{2}$ and $\mathrm{HCO}_{3}^{-}$transport by cyanobacteria: a review, Can. J. Bot., 68, 1291-1302, https://doi.org/10.1139/b90-165, 1990.

Millo, C., Dupraz, S., Ader, M., Guyot, F., Thaler, C., Foy, E., and Ménez, B.: Carbon isotope fractionation during calcium carbonate precipitation induced by ureolytic bacteria, Geochim. Cosmochim. Ac., 98, 107-124, https://doi.org/10.1016/j.gca.2012.08.029, 2012.

Möller, H.: The influence of $\mathrm{Mg}^{2+}$ on the formation of calcareous deposits on a freely corroding low carbon steel in seawater, Corros. Sci., 49, 1992-2001, https://doi.org/10.1016/j.corsci.2006.10.011, 2007.

Morse, J. W., Gledhill, D. K., and Millero, F. J.: $\mathrm{CaCO}_{3}$ precipitation kinetics in waters from the great Bahama bank: Implications for the relationship between bank hydrochemistry and whitings, Geochim. Cosmochim. Ac., 67, 2819-2826, https://doi.org/10.1016/S0016-7037(03)00103-0, 2003.

Morse, J. W., Arvidson, R. S., and Lüttge, A.: Calcium carbonate formation and dissolution, Chem. Rev., 107, 342-381, https://doi.org/10.1021/cr050358j, 2007.

Nguyen Dang, D., Gascoin, S., Zanibellato, A., Da Silva, C., Lemoine, M., Riffault, B., Sabot, R., Jeannin, M., Chateigner, D., and Gil, O.: Role of brucite dissolution in calcium carbonate precipitation from artificial and natural seawaters, Cryst. Growth Des., 17, 1502-1513, https://doi.org/10.1021/acs.cgd.6b01305, 2017.

Nothdurft, L. D., Webb, G. E., Buster, N. A., Holmes, C. W., Sorauf, J. E., and Kloprogge, J. T.: Brucite microbialites in living coral skeletons: Indicators of extreme microenvironments in shallow-marine settings, Geology, 33, 169-172, https://doi.org/10.1130/g20932.1, 2005.

Obst, M., Dynes, J. J., Lawrence, J. R., Swerhone, G. D. W., Benzerara, K., Karunakaran, C., Kaznatcheev, K., Tyliszczak, T., and Hitchcock, A. P.: Precipitation of amorphous $\mathrm{CaCO}_{3}$ (aragonitelike) by cyanobacteria: A STXM study of the influence of EPS on the nucleation process, Geochimi. Cosmochimi. Ac., 73, 41804198, https://doi.org/10.1016/j.gca.2009.04.013, 2009a.

Obst, M., Wehrli, B., and Dittrich, M.: $\mathrm{CaCO}_{3}$ nucleation by cyanobacteria: laboratory evidence for a passive, surface-induced mechanism, Geobiology, 7, 324-347, https://doi.org/10.1111/j.1472-4669.2009.00200.x, 2009b.

Orange, F., Chabin, A., Gorlas, A., Lucas-Staat, S., Geslin, C., Le Romancer, M., Prangishvili, D., Forterre, P., and Westall, F.: Experimental fossilisation of viruses from extremophilic Archaea, Biogeosciences, 8, 1465-1475, https://doi.org/10.5194/bg-81465-2011, 2011.

Pacton, M., Wacey, D., Corinaldesi, C., Tangherlini, M., Kilburn, M. R., Gorin, G. E., Danovaro, R., and Vasconcelos, C.: Viruses as new agents of organomineralization in the geological record, Nat. Commun., 5, 4298-4298, https://doi.org/10.1038/ncomms5298, 2014.

Patel, A., Noble, R. T., Steele, J. A., Schwalbach, M. S., Hewson, I., and Fuhrman, J. A.: Virus and prokaryote enumera- tion from planktonic aquatic environments by epifluorescence microscopy with SYBR Green I, Nat. Protoc., 2, 269-276, https://doi.org/10.1038/nprot.2007.6, 2007.

Peng, X., Xu, H., Jones, B., Chen, S., and Zhou, H.: Silicified viruslike nanoparticles in an extreme thermal environment: implications for the preservation of viruses in the geological record, Geobiology, 11, 511-526, https://doi.org/10.1111/gbi.12052, 2013.

Perri, E., Tucker, M. E., Słowakiewicz, M., Whitaker, F., Bowen, L., and Perrotta, I. D.: Carbonate and silicate biomineralization in a hypersaline microbial mat (Mesaieed sabkha, Qatar): Roles of bacteria, extracellular polymeric substances and viruses, Sedimentology, 65, 1213-1245, https://doi.org/10.1111/sed.12419, 2017.

Planavsky, N., Reid, R. P., Lyons, T. W., Myshrall, K. L., and Visscher, P. T.: Formation and diagenesis of modern marine calcified cyanobacteria, Geobiology, 7, 566-576, https://doi.org/10.1111/j.1472-4669.2009.00216.x, 2009.

Ridgwell, A. and Zeebe, R. E.: The role of the global carbonate cycle in the regulation and evolution of the Earth system, Earth. Planet. Sc. Lett., 234, 299-315, https://doi.org/10.1016/j.epsl.2005.03.006, 2005.

Riding, R.: Cyanobacterial calcification, carbon dioxide concentrating mechanisms, and Proterozoic-Cambrian changes in atmospheric composition, Geobiology, 4, 299-316, https://doi.org/10.1111/j.1472-4669.2006.00087.x, 2006.

Riding, R.: Calcified Cyanobacteria, in: Encyclopedia of Geobiology, edited by: Reitner, J. and Thiel, V., Springer Netherlands, Dordrecht, 211-223, 2011.

Riding, R.: A Hard Life for Cyanobacteria, Science, 336, 427-428, https://doi.org/10.1126/science.1221055, 2012.

Rodriguez-Blanco, J. D., Shaw, S., and Benning, L. G.: How to make "stable" ACC: protocol and preliminary structural characterization, Mineral. Mag., 72, 283-286, https://doi.org/10.1180/minmag.2008.072.1.283, 2008.

Rohwer, F. and Thurber, R. V.: Viruses manipulate the marine environment, Nature, 459, 207-212, https://doi.org/10.1038/nature08060, 2009.

Semesi, I. S., Kangwe, J., and Björk, M.: Alterations in seawater $\mathrm{pH}$ and $\mathrm{CO}_{2}$ affect calcification and photosynthesis in the tropical coralline alga, Hydrolithon sp. (Rhodophyta), Estuar. Coast. Shelf S., 84, 337-341, https://doi.org/10.1016/j.ecss.2009.03.038, 2009.

Suttle, C. A.: Viruses in the sea, Nature, 437, 356-361, https://doi.org/10.1038/nature04160, 2005.

Suttle, C. A.: Marine viruses - major players in the global ecosystem, Nat. Rev. Microbiol., 5, 801-812, https://doi.org/10.1038/nrmicro1750, 2007.

Suttle, C. A. and Chan, A. M.: Dynamics and distribution of cyanophages and their effect on marine Synechococcus spp., Appl. Environ. Microb., 60, 3167-3174, 1994.

Tesson, B., Gaillard, C., and Martin-Jézéquel, V.: Brucite formation mediated by the diatom Phaeodactylum tricornutum, Mar. Chem., 109, 60-76, https://doi.org/10.1016/j.marchem.2007.12.005, 2008.

Weiner, S. and Addadi, L.: Crystallization pathways in biomineralization, Annu. Rev. Mater. Res., 41, 21-40, https://doi.org/10.1146/annurev-matsci-062910-095803, 2011. 
Weitz, J. S. and Wilhelm, S. W.: Ocean viruses and their effects on microbial communities and biogeochemical cycles, F1000 biology reports, Vol. 4, https://doi.org/10.3410/B4-17, 2012.

Wright, D. T. and Oren, A.: Nonphotosynthetic bacteria and the formation of carbonates and evaporites through time, Geomicrobiol. J., 22, 27-53, https://doi.org/10.1080/01490450590922532, 2005.
Yang, Z.-N., Li, X.-M., Umar, A., Fan, W.-H., and Wang, Y.: Insight into calcification of Synechocystis sp. enhanced by extracellular carbonic anhydrase, RSC Adv., 6, 29811-29817, https://doi.org/10.1039/C5RA26159G, 2016. 